\title{
The Comparison of Functional Capacity Improvement after Pulmonary Rehabilitation between COPD Groups with Different Exacerbation History
}

\section{Budiati Laksmitasari1, Siti Chandra Widjanantie ${ }^{2}$, Nury Nusdwinuringtyas ${ }^{1}$}

${ }^{1}$ Department of Physical Medicine and Rehabilitation, Faculty of Medicine, University of Indonesia, Jakarta, Indonesia.

${ }^{2}$ Department of Physical Medicine and Rehabilitation, Persahabatan National Respiratory Hospital, Jakarta, Indonesia.

\begin{abstract}
Backgrounds: Pulmonary rehabilitation may improve functional capacity in chronic obstructive pulmonary disease (COPD). This study aimed to know the effect of 2-month pulmonary rehabilitation in the functional capacity of the patient with stable COPD and compare the functional capacity change based on exacerbation history.

Methods: This was retrospective cohort study. The subjects were patients with stable COPD who underwent pulmonary rehabilitation in Persahabatan National Respiratory Hospital, between February 2018 and January 2019. Functional capacity was evaluated by 6-minute walking distance (6MWD) before and after 2-month pulmonary rehabilitation. The 6MWD change was compared between COPD group A-B and group C-D.

Results: Of the 14 subjects, the 6MWD was significantly improved in all subjects ( $\mathrm{p}=0.001)$. The median of 6MWD change was 32 (6-235) $\mathrm{m}$. The 6MWD improvement was 35 (7-84) $\mathrm{m}$ in COPD group A-B and 29 (6-235) $\mathrm{m}$ in COPD group C-D. There was no significant difference in 6MWD improvement between both groups $(p=1.000)$.
\end{abstract}

Conclusion: Two-month pulmonary rehabilitation may improve functional capacity in the patient with stable COPD regardless of the exacerbation history.

Keywords: pulmonary rehabilitation, COPD, $6 M W D, A B C D$ groups, exacerbation history 


\section{ABSTRAK}

Latar belakang: Rehabilitasi paru telah terbukti meningkatkan kapasitas fungsional pada Penyakit Paru Obstruktif Kronik (PPOK). Penelitian ini bertujuan untuk mengetahui pengaruh rehabilitasi paru selama 2 bulan terhadap kapasitas fungsional pada pasien dengan PPOK stabil dan membandingkan perubahan kapasitas fungsional berdasarkan riwayat eksaserbasi.

Metode: Desain penelitian adalah kohort retrospektif. Subjek adalah pasien dengan PPOK stabil yang menjalani rehabilitasi paru di Rumah Sakit Persahabatan, antara Februari 2018 dan Januari 2019. Kapasitas fungsional dievaluasi dengan uji jalan 6 menit sebelum dan sesudah rehabilitasi paru selama 2 bulan. Perubahan jarak tempuh uji jalan enam menit (6MWD) dibandingkan antara grup PPOK A-B dan grup PPOK C-D.

Hasil: Dari 14 subjek, 6MWD meningkat secara signifikan pada semua subjek $(\mathrm{p}=0.001)$. Median peningkatan 6MWD adalah 32 (6-235) $\mathrm{m}$. Peningkatan 6MWD sebesar 35 (7-84) m pada grup PPOK A-B dan 29 (6-235) m pada grup PPOK C-D. Tidak ada perbedaan signifikan dalam peningkatan 6MWD antara kedua grup $(\mathrm{p}=1.000)$.

Kesimpulan: Rehabilitasi paru selama 2 bulan dapat meningkatkan kapasitas fungsional pada pasien dengan PPOK stabil terlepas dari riwayat eksaserbasi.

Kata Kunci: pulmonary rehabilitation, COPD, $6 M W D$, $A B C D$ groups, exacerbation history

\section{Correspondent Detail:}

\section{Budiati Laksmitasari}

Email: blaksmitasari@gmail.com

Department of Medical Rehabilitation, Faculty of Medicine-University of Indonesia, Cipto Mangunkusumo Hospital.

Address: Jl. Pangeran Diponegoro No.71.

Kenari, Jakarta Pusat.

\section{INTRODUCTION}

Chronic obstructive pulmonary disease (COPD) is the fourth leading cause of death in the world recently. ${ }^{1}$ According to RISKESDAS in the year 2013, COPD is the second most prevalent non- infectious disease in Indonesia $(3.7 \%){ }^{2}$ COPD is an obstructive and progressive airway disease characterized by persistent respiratory symptoms and air limitation due to airways and/or alveolar abnormalities usually caused by significant exposure to noxious particles or gases. ${ }^{3}$ In the past, a simple measure of breathlessness such as the Modified British Research Council (mMRC) questionnaire was considered adequate for symptoms assessment. However, it is now recognized that COPD impacts patients more than just dyspnea, therefore, a comprehensive assessment of symptoms is recommended. COPD Assessment Test (CAT) is the shorter version of the comprehensive disease-specific health status questionnaire. It consists of an 8-item unidimensional measurement of health status impairment in COPD. The score ranges from $0-40$, and the equivalent cut-point is $10,{ }^{4,5}$ 
A refinement of the $\mathrm{ABCD}$ assessment tool is proposed that separates spirometric grades from the "ABCD" groups. For some therapeutic recommendations, $\mathrm{ABCD}$ groups will be derived exclusively from patient symptoms and history of exacerbation. The new approach to combined COPD assessment according to Global Initiative

\begin{tabular}{|c|c|c|}
\hline $\begin{array}{c}\text { Spirometrically } \\
\text { confirmed } \\
\text { diagnosis }\end{array}$ & & $\begin{array}{l}\text { essment } \\
\text { airflow } \\
\text { nitation }\end{array}$ \\
\hline \multirow{5}{*}{$\begin{array}{c}\text { Post- } \\
\text { bronchodilator } \\
\text { FEV }_{1} / \text { FVC }<0.7\end{array}$} & Grade & $\begin{array}{c}\mathrm{FEV}_{1} \\
\text { (\% predicted) }\end{array}$ \\
\hline & Gold 1 & $\geq 80$ \\
\hline & Gold 2 & $50-79$ \\
\hline & Gold 3 & $30-49$ \\
\hline & Gold 4 & $<\mathbf{3 0}$ \\
\hline
\end{tabular}

for Chronic Obstructive Lung Disease (GOLD) 2019 is illustrated in figure 1. Patients with 0 or 1 moderate exacerbation history in the past year are classified into group A or B. Patients with 2 or more moderate exacerbation history or any exacerbation history leading to hospital admission are classified into group $\mathrm{C}$ or $\mathrm{D} .^{3}$
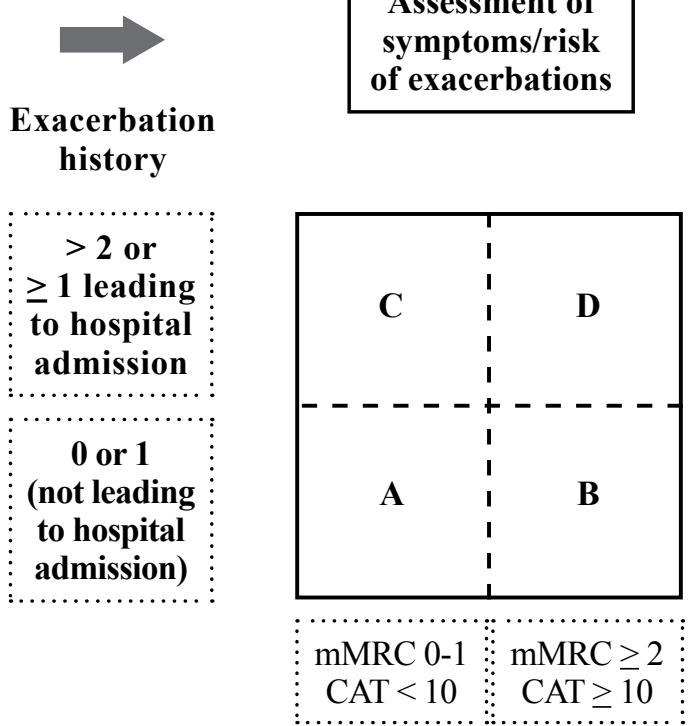

Symptoms

Figure 1. The refined $A B C D$ assessment tool ${ }^{3}$

COPD also associated with an important reduction in functional exercise capacity and psychological problems that contribute to the patient's disability. ${ }^{6}$ Six-minute walking test (6MWT) is a valid, reliable test used in the management of COPD patients because it can measure both the changes in the functional exercise capacity and response to the pulmonary rehabilitation program. Many hospitals use 6MWT not only because it assesses the outcome of any treatment effects, but also because it is inexpensive, noninvasive, easy to do, and measures patient disability as well as capability. ${ }^{7}$

There are several studies show that pulmonary rehabilitation improves functional capacity in
COPD. Pulmonary rehabilitation has been defined as "a multidimensional continuum of services directed to persons with pulmonary disease and their families, usually by an interdisciplinary team of specialists, to achieve and maintain the individual's maximum level of independence and functioning in the community". 8

A systematic review of Randomized Controlled Trials (RCTs) by McCarthy et al. concluded that pulmonary rehabilitation relieves dyspnea and fatigue, improves emotional function, enhances the sense of control that individuals have over their condition, and also improves functional capacity. ${ }^{9}$ Lahham et al. conducted a metaanalysis of RCTs and found that exercise training 
alone, or with the addition of activity counseling, significantly improved physical activity levels in COPD patients. ${ }^{10}$

The British Thoracic Society Guideline summarized the role of pulmonary rehabilitation for COPD to three primary roles 1) improving exercise capacity, 2) improving dyspnea, and 3) improving psychological wellbeing. ${ }^{11}$ The components of pulmonary rehabilitation may vary but evidence-based practice for program delivery includes: structures and supervised exercise training, smoking cessation, nutrition counseling, and self-management education. ${ }^{12}$

Several studies have compared the improvement of functional capacity after pulmonary rehabilitation between different baseline conditions in COPD. ${ }^{13-17}$ Ergün et al. evaluated the outcome of the pulmonary rehabilitation program in COPD patients to find if the pulmonary rehabilitation program in the late stage of COPD was effective as in the early stage of the disease. The improvement of the functional capacity was not significantly different in both stages. ${ }^{14}$ Study by Alosaimi showed the improvement of 6MWD and Chronic Respiratory Questionnaire (CRQ) after pulmonary rehabilitation in COPD. They compared the improvement between four groups according to the GOLD classification of airflow limitation. ${ }^{15}$ A study by Shehata et al. reported that pulmonary rehabilitation for patients with stable COPD is effective for improving exercise capacity. They reported the significant correlation of the functional capacity improvement with the dyspnea score, quality of life, airflow limitation and baseline exercise capacity. ${ }^{16}$

There was no study which compared the improvement of functional capacity after pulmonary rehabilitation between COPD with different exacerbation history. The aims of this study were 1) to know the effect of 2-month pulmonary rehabilitation in functional capacity in patients with stable COPD, and 2) to compare functional capacity change after pulmonary rehabilitation in stable COPD based on exacerbation history.

\section{METHODS}

\section{Subjects}

The subjects were patients with COPD groups $\mathrm{A}, \mathrm{B}, \mathrm{C}$, and $\mathrm{D}$ who underwent pulmonary rehabilitation in Medical Rehabilitation Clinic at Persahabatan National Respiratory Hospital, between February 2018 and January 2019. All the subjects who underwent pulmonary rehabilitation were not in exacerbation of their disease (stable COPD). The subjects who did not perform 6MWT before or after 2-month pulmonary rehabilitation were excluded from the study.

\section{Study design}

The design was a retrospective cohort study. We collected data from medical records of patients in Medical Rehabilitation Clinic at Persahabatan National Respiratory Hospital who met the subjects criteria as mentioned above. The functional capacity was evaluated by $6 \mathrm{MWD}$ before and after the pulmonary rehabilitation program. The 6MWD change was compared between two groups of subjects based on the same exacerbation history. One group was subjects with COPD groups A and B (group A-B). The other group was subjects with COPD groups $\mathrm{C}$ and D (group C-D). The subjects were classified into one of the groups according to the $\mathrm{ABCD}$ assessment tool (figure 1). ${ }^{3}$ 


\section{Pulmonary rehabilitation}

The interventions that were given to the subjects were pulmonary rehabilitation program. The program was individually prescribed but generally consist of medical education, relaxation technique, flexibility exercise, breathing exercise, and aerobic training with a static cycle or treadmill. The subjects perform the program 3 times per week for 2 months. The estimation of aerobic training workload was based on The Cooper Clinic and Research Institute Fitness Series with some modifications.

\section{$6 M W T$}

The functional capacity was measured with 6MWT before and after the 2-month pulmonary rehabilitation program. The medical staff who performed the test was a Resident of Physical Medicine and Rehabilitation. The vital sign, Borg Scale, and any subjective complaint were observed before and after the test. The subjects walked as far as possible on the track for 6 minutes. At each minute during the walk, the medical staff told the participant how much time had elapsed and the remaining time and gave scripted encouragement. At the end of the 6 minutes, the participant was told to stop, and the distance walked was recorded. The walking distance in 6 minutes was measured as 6-minute walking distance (6MWD) and was recorded at the medical record. ${ }^{7,17}$

\section{Statistical analysis}

All statistical analyses were carried out with SPSS for Windows version 20. Saphiro-Wilk was used to test the normality of numerical data distribution. To compare 6MWD before and after pulmonary rehabilitation program, two dependent t-tests would be used if the data distributions were normal, and the Wilcoxon test would be used if the data distributions were not normal. The difference of 6MWD between COPD group A-B and COPD group C-D was compared by independent t-test if the data distributions were normal, or Mann-Whitney test if the data distributions were not normal. The alpha level was $5 \%$.

\section{RESULTS}

Fourteen subjects were included in this study. The subjects were mainly male $(73.7 \%)$ with a mean of age $59 \pm 6$ years old. The subjects included in the analysis showed similar distribution among the COPD group A-B and group C-D (Table 1).

Table 1. Characteristics of subjects

\begin{tabular}{lcc}
\hline & $\mathrm{n}(\%)$ & Mean \pm SD \\
\hline Sex & & \\
Male & $11(73.3 \%)$ & \\
Female & $3(20.0 \%)$ & \\
Age (years) & & $59 \pm 6$ \\
Group & & \\
A-B & $7(46.7 \%)$ & \\
C-D & $7(46.7 \%)$ & \\
\hline
\end{tabular}

The median of 6MWD before the pulmonary rehabilitation program was $358(116-450) \mathrm{m}$. The 6MWD was improved in all subjects. The median of 6MWD change after 2-month pulmonary rehabilitation was 32 (6-235) $\mathrm{m}$ (Table 2). The 6MWD before and after pulmonary rehabilitation was significantly different $(\mathrm{p}=0.001)$. 
Table 2. Median of 6MWD before and after pulmonary rehabilitation

\begin{tabular}{ccccc}
\hline & Before & After & Difference & p-value \\
\hline 6MWD (m) & $358(116-450)$ & $404,5(315-489)$ & $32(6-235)$ & $0.001^{*}$ \\
\hline
\end{tabular}

${ }^{*}$ Wilcoxon test; data represent median (range)

The comparison of $6 \mathrm{MWD}$ between groups was shown in Table 3. The 6MWD before and after pulmonary rehabilitation program in COPD group A-B were higher than group C-D. The improvement of 6MWD in group A-B 35 (784) $\mathrm{m}$ was higher than group C-D $29(6-235) \mathrm{m}$. There was no significant difference in $6 \mathrm{MWD}$ change COPD group A-B and C-D. $(p=1.000)$.

Table 3. Comparison of 6MWD between COPD group A-B and group C-D

\begin{tabular}{lccc}
\hline & Group A-B & Group C-D & p-value \\
\hline 6MWD pre program (m) & $378(324-409)$ & $327(116-450)$ & \\
6MWD post program (m) & $427(339-489)$ & $351(315-479)$ & \\
6MWD difference (m) & $35(7-84)$ & $29(6-235)$ & $1.000^{*}$ \\
\hline
\end{tabular}

*Mann-whitney test; data represent median (range)

\section{DISCUSSION}

Our study evaluated the short-term effects of a supervised pulmonary rehabilitation program in an outpatient setting with stable COPD patients. All the subjects in COPD group A to $\mathrm{D}$ showed improvement in functional capacity after the 2-month program, based on the improvement of 6MWD. The effectiveness of pulmonary rehabilitation in improving exercise performance was similar to a systematic review by McCarthy et al and meta-analysis by Lahham et al. ${ }^{9,10}$ The change of 6MWD was 32 (6-235) $\mathrm{m}$, which exceeded its minimum clinically important difference $(25-35 \mathrm{~m})$. This is similar to previous study findings by McCarthy, that showed greater 6MWD treatment effect than the threshold of clinical significance. ${ }^{9}$

The result of our study showed that the 2-month pulmonary rehabilitation program gives no significant difference in 6MWD improvement among COPD group A-B and group C-D $(p=1.000)$. This study aimed to compare the functional capacity change after pulmonary rehabilitation based on exacerbation history. Thus, we divided the subjects into the two groups based on the same exacerbation history, according to the refined $\mathrm{ABCD}$ assessment tool. ${ }^{3}$ The result showed that pulmonary 
rehabilitation resulted in functional capacity improvement independent of exacerbation history.

Our results are in line with previous studies that compared the effectiveness of 2-month pulmonary rehabilitation between different baseline conditions. ${ }^{14,15}$ They showed that the improvement of functional capacity was not significantly different between different stages and degree of airflow limitation. Ergün et al. compared the effects of 2-month pulmonary rehabilitation between the early and late stages of COPD. For both groups, there was a statistically significant improvement in dyspnea scores (evaluated by MRC), health-related quality of life, functional capacity, and psychological status. Regardless of the disease severity, patients responded very well to the program, both in the early stage and late stage of the disease. ${ }^{14}$ A study by Alosaimi divided the subjects into four groups according to the GOLD classification of airflow limitation in patients with FEV1/FVC $<0.70$. They showed that there was a significant difference between 6MWD before and after pulmonary rehabilitation. All the groups responded positively to the program with no significantly different responses. ${ }^{15}$

Otherwise, a study by Shehata et al. reported that functional capacity improvement significantly correlated with several baseline conditions. The improvement in 6MWD after 2-month pulmonary rehabilitation was inversely correlated with the dyspnea score and quality of life. They also showed that the improvement in 6MWD was significantly directly correlated with the degree of airflow limitation and baseline functional capacity. ${ }^{16}$ However, previous studies did not compare the effects of pulmonary rehabilitation between different exacerbation history.
Pulmonary rehabilitation gives benefits to COPD patients in many aspects as it can improve health-related quality of life, reduce dyspnea, improve exercise performance, and reduce re-exacerbations events. The components of the pulmonary rehabilitation program in our study include supervised exercise training and medical education, which was met the requirement of pulmonary rehabilitation program components. ${ }^{12}$ Supervised exercise training in our study includes aerobic training, flexibility exercise, and breathing exercise. Aerobic training was performed by a treadmill or ergo cycle, which was prescribed individually based on the 6MWD result. Flexibility exercise of the trunk and extremities was aimed to maintain long term joint mobility and flexibility. Breathing exercise includes active cycle breathing techniques to promote airway clearance, diaphragmatic breathing, and chest mobilization exercise to improve thoracic cage mobility and train the respiratory muscle. ${ }^{6,18,19}$ Airway secretion clearance is crucial because exacerbations of COPD are caused by trapping of airway secretions in the peripheral airways. Diaphragmatic and pursed-lip breathing can also help to decreases the respiratory rate, coordinates the breathing pattern, improve blood gases, and decrease tension and anxiety. ${ }^{8}$

This is the first study that compared functional capacity change after 2-month pulmonary rehabilitation in stable COPD based on exacerbation history. The limitations of this study are the sample size and retrospective design. More studies with bigger sample size and prospective study design are needed to confirm the difference in pulmonary rehabilitation program effects between COPD groups with different exacerbation history. 


\section{CONCLUSION}

The functional capacity of the patient with stable COPD was significantly improved after 2-month pulmonary rehabilitation. The improvement was not significantly different among COPD group A-B and COPD group C-D. Pulmonary rehabilitation may improve functional capacity in all stable COPD regardless of the exacerbation history.

\section{REFERENCES}

1. Lozano R, Naghavi M, Foreman K, et al. Global and regional mortality from 235 causes of death for 20 age groups in 1990 and 2010: a systematic analysis for the global burden of disease study 2010. Lancet. 2012;380(9859):2095-128

2. Badan Penelitian dan Pengembangan Kesehatan Kementerian Kesehatan RI Tahun 2013, KEMENTERIAN KESEHATAN RI, TAHUN 2013. Riset Kesehatan Dasar 2013 [Internet]. 2013 [cited 2019 Feb 23]. Available from: http://www.depkes.go.id/resources/ download/general/Hasil\%20Riskesdas $\% 20$ 2013.pdf

3. GOLD 2019. Global Strategy for the Diagnosis, Management and Prevention of COPD. Global Initiative for Chronic Obstructive Lung Disease - GOLD.

4. Karloh M, Fleig Mayer A, Maurici R, Pizzichini MM, Jones PW, Pizzichini E. The COPD assessment test: what do we know so far? a systematic review and meta-analysis about clinical outcomes prediction and classification of patients into GOLD stages.
Chest. 2016;149(2):413-25.

5. Jones PW, Tabberer M, Chen WH. Creating scenarios of the impact of COPD and their relationship to COPD Assessment Test (CAT) scores. BMC Pulm Med. 2011;11:42.

6. Corhay JL, Dang DN, Van Cauwenberge H, Louis R. Pulmonary rehabilitation and COPD: providing patients a good environment for optimizing therapy. Int J COPD. 2013;9:2739.

7. ATS Statement. Am J Respir Crit Care Med, 2012; 166(1): 111-7. [cited 2019 Feb 23]. Available from: https://doi.org/10.1164/ ajrccm.166.1.at1102

8. Bach JR, Altschuler E. Rehabilitation of the patient with respiratory dysfunction. In: Frontera WR, Delisa JA. Delisa's physical medicine \& rehabilitation. 5th ed. Philadelphia: Lippincott williams \& wilkins; 2010. p. 1099-124.

9. McCarthy B, Casey D, Devane D, Murphy K, Murphy E, Lacasse Y. Pulmonary rehabilitation for chronic obstructive pulmonary disease. Cochrane Database of Systematic Reviews 2015, Issue 2. Art. No.: CD003793.

10. Lahham A, McDonald CF, Holland AE. Exercise training alone or with the addition of activity counseling improves physical activity levels in COPD: a systematic review and meta-analysis of randomized controlled trials. Int J Chron Obstruct Pulmon Dis. 2016;11:3121-36.

11. Bolton CE, Bevan-Smith, EF, Blakey JD, Crowe P, Elkin SL, Garrod R. British Thoracic Society guideline on pulmonary rehabilitation in adults: accredited by NICE. 
Thorax. 2013;68(Suppl 2):111-30.

12. Spruit MA, Singh SJ, Garvey C, et al. An official American Thoracic Society/European Respiratory Society statement: key concepts and advances in pulmonary rehabilitation. Am J Respir Crit Care Med. 2013;188(8):e13-64.

13. Puhan MA, Spaar A, Frey M, Turk A, Brändli $\mathrm{O}$, Ritscher $\mathrm{D}$, et al. Early versus late pulmonary rehabilitation in chronic obstructive pulmonary disease patients with acute exacerbations: a randomized trial. Respiration; International Review of Thoracic Diseases. 2012;83(6):499-506.

14. Ergün P, Kaymaz D, Günay E, Erdoğan Y, Turay UY, Demir N, et al. Comprehensive out-patient pulmonary rehabilitation: Treatment outcomes in early and late stages of chronic obstructive pulmonary disease. Ann Thorac Med. 2011;6(2):70-6.

15. Alosaimi S. "When to initiate pulmonary rehabilitation program for chronic obstructive pulmonary disease patients." Thesis, Georgia State University, 2018. [cited 2019 Apr 23]. Available from: https://scholarworks.gsu. edu/rt theses $/ 43$.
16. Shehata SM, Refky MM, Al gabry MM, Nafae RM. Outcome of pulmonary rehabilitation in patients with stable chronic obstructive pulmonary disease at Chest Department, Zagazig University Hospitals (2014-2016). Egypt J Bronchol. 2018;12:279-87.

17. Bennell K, Dobson F, Hinman R. Measures of physical performance assessments: SelfPaced Walk Test (SPWT), Stair Climb Test (SCT), Six-Minute Walk Test (6MWT), Chair Stand Test (CST), Timed Up \& Go (TUG), Sock Test, Lift and Carry Test (LCT), and Car Task. Arthritis Care Res. 2011;63(S11):S350-70.

18. Gloecki R, Marinov B, Pitta F. Practical Recommendation for exercise training in patients with COPD. Eur Respir Rev. 2013;22:178-86.

19. Thockom SK, Gulati K, et al. Effects of yogic intervention on pulmonary functions and health status in patients of COPD and the possible mechanisms. Complementary Therapies in Clinical Practice. 2018;33:20-6. 